\title{
Razvoj slovenske paremiologije in paremiološke terminologije ${ }^{1}$
}

\author{
NATALIJA ULČNIK \\ Univerza v Mariboru, Filozofska fakulteta, Koroška cesta 160, \\ SI-2000 Maribor,natalija.ulcnik@um.si
}

\begin{abstract}
Prispevek se osredinja na terminološka vprašanja v okviru paremiologije - vede, ki preučuje pregovore in njim sorodne enote. Izpostavlja vprašanje njene znanstvene avtonomnosti in problematiko definiranja osnovne enote preučevanja, torej paremije. V sklepnem delu je poudarjena potreba po novih jezikoslovnih paremioloških raziskavah, ki bodo $\mathrm{v}$ prihodnje pripomogle tudi k terminološkemu izčiščevanju.
\end{abstract}

The article focuses on terminology referred to paremiology - a science which examines proverbs and related units. It outlines the question of paremiology's scientific autonomy and the problem of defining the basic units of the study, i.e. paremia. In the conclusion the analysis emphasizes a need for new paremiological linguistic researches that will also help to expand terminology.

Ključne besede: paremiologija, paremija, pregovorne enote, terminologija

Key words: paremiology, paremia, proverbial units, terminology

\section{Uvod}

Oblikovanje terminologije je bistveno za razvoj vsakega strokovnega področja. Za uspešno sporazumevanje med strokovnjaki naj bi bila terminologija urejena in usklajena, zato se ta pogosto zbira in leksikografsko ureja (Žagar Karer 2011: 124). V nadaljevanju je prikazano, kako se je v slovenskem prostoru razvijala paremiologija in njeno izrazje, pri tem pa je opozorjeno zlasti na definicijsko problematiko osnovne enote, tj. paremije.

\footnotetext{
${ }^{1}$ Prispevek je nastal v okviru programske skupine Slovensko jezikoslovje, književnost in poučevanje slovenščine (P6-0156).
} 


\section{1 (Ne)avtonomnost paremiologije}

Paremiologija (pregovoroslovje), ki se znanstveno ukvarja s paremiološkimi (pregovornimi) enotami (v nadaljevanju PE), je opredeljena kot veja določene vede, ${ }^{2}$ kot neavtonomna znanstvena disciplina brez lastne metodologije ${ }^{3} \mathrm{oz}$. kot izrazito interdisciplinarno področje. PE se namreč kot raziskovalno gradivo pojavljajo pri mnogih humanistično-družboslovnih vedah, npr. v slovstveni folkloristiki, jezikoslovju, kulturologiji, antropologiji, sociologiji, psihologiji. ${ }^{4}$ Zaradi večperspektivne obravnave je lahko paremiološka terminologija sicer zelo razvejana in izdelana, a hkrati neenotna in neenoznačna, kar se pokaže že ob poskusu definiranja osnovne enote preučevanja, torej pregovora (prim. Norrick 2015). Ob tem se porajajo vprašanja: ali se lahko paremiologija (kot podveda) kdaj povsem osamosvoji, ${ }^{5}$ ali je njen znanstveni aparat dovolj razvit, predvsem pa, ali ima ustaljeno strokovno izrazje oz. ali zadostuje kriteriju izrazne homogenosti.

\subsection{Paremiologija znotraj jezikoslovja}

Znotraj jezikoslovja ${ }^{6}$ se s pregovori natančneje ukvarjajo frazeologija, leksikografija, kontrastivno jezikoslovje, kognitivno jezikoslovje, psiholingvistika, etnolingvistika, sociolingvistika in lingvokulturologija. Frazeologija v širšem smislu namreč zajema tudi enote z vrednostjo povedi, torej pregovore (Keber 2011: 9; Kržišnik 2013: 18-19); leksikografija v okviru vsega slovarskega gradiva pregovore preučuje kot posebne enote, in sicer $\mathrm{z}$ vidika njihove makro- in mikrostrukturne vključenosti v eno-, dvo- in večjezične slovarje ter $\mathrm{z}$ vidika slovarske oblike, variantnosti, pomensko-pragmatičnega pojasnjevanja (prim. Jesenšek 2007, Jesenšek, Ulčnik 2014); ${ }^{7}$ pri kontrastivnem jezikoslovju so v ospredju medjezikovni paremiološki vplivi, podobnosti in razlike v paremiološkem gradivu, iskanje ustreznikov (prim. Jesenšek 2008, Meterc 2013, Bernjak 2013, Ďurčo, Meterc 2013, Ďurčo, Meterc 2014); kognitivno jezikoslovje izpostavlja abstrahirane sheme, po katerih pregovore razumemo, zaznavamo,

${ }^{2}$ Npr. slovstvene folkloristike (Babič 2011).

3 »However, paremiology is no discipline in its own right, or with its own method /.../« (Grzybek 2008: 30).

${ }^{4}$ Prim. seznam objav s področja paremiologije v Mieder, Sobieski 2003.

${ }^{5}$ Aktualno je tudi vprašanje, ali obstaja potreba po njeni avtonomiji. Za sodobno znanost je namreč značilno prav povezovanje znanj različnih ved, interdisciplinarnost je torej na nek način že njena inherentna značilnost (prim. Ožbot 2011).

${ }^{6}$ Jezikoslovne paremiološke raziskave se osredinjajo na »zgradbene, pomenske in funkcijske lastnosti pregovorov« (Jesenšek 2007: 276).

${ }^{7} \mathrm{~V}$ primeru slovarskega prikazovanja zgolj paremiološkega gradiva govorimo o leksikografiji pregovorov oz. o paremiografiji (Grzybek 2013: 27; prim. tudi 10. poglavje v monografiji Introduction to Paremiology, 2015). 
uporabljamo in shranjujemo v mentalnem leksikonu (prim. Kržišnik 2004, Fabčič, Bernjak 2014), psiholingvistika se ukvarja s priklicem ustreznih enot iz spomina in z njihovo ustrezno interpretacijo (prim. ustrezno bibliografijo v Mieder, Sobieski 2003); ${ }^{8}$ etnolingvistika jezik razume kot izraz kulture, človekovih vrednot, prepričanj in podobno (Babič 2011: 28), zato raziskuje, kako na rabo pregovorov vplivajo običaji, verovanja ipd.; sociolingvistika pregovore preučuje Z vidika različnih parametrov, npr. spola, starosti, izobrazbe (prim. Lipavic Oštir 2014); lingvokulturologija izpostavlja kulturno konotacijo pregovorov (Kržišnik 2008, Fabčič, Bernjak 2014). ${ }^{9}$

\section{Prve paremiološke zbirke na Slovenskem}

Četudi se paremiološka terminologija na Slovenskem še oblikuje, pa se je znanost o pregovorih začela razvijati že v starogrškem obdobju (Babič 2011: 27). V slovenskem prostoru se je izraz paremiologia pojavil že v najzgodnejšem obdobju slovenskega knjižnega jezika, in sicer v dveh delih H. Megiserja, ki veljata za najstarejšo zbirko slovenskih pregovorov: Paroemiologias: Sententiae insigniores (1592) in Paroemiologia Polygllottos, hoc est Proverbia et Sententiae complurium linguarum (1603). Pregovori so se začeli intenzivneje zbirati in pozitivno vrednotiti v obdobju narodnega preporoda (prim. Stanonik 1995). Takrat so bili ljudje pozvani k zbiranju t. i. narodnega blaga in njihove zbirke so se objavljale v tedanjem časopisju. Vezane so bile tudi na pregovorom sorodno gradivo in v nekaterih primerih so ga poskušale razločevati že v naslovju, npr. Pregovori, izreki in pametnice; Izreki in pregovori; Prislovice in reki isterski (prim. Ulčnik 2014a). Konec 19. stoletja sta nastali tudi dve samostojni knjižni objavi pregovornih enot: (1) Pregovori (1883) in (2) Pregovori, prilike in reki Frana Kocbeka (1887). ${ }^{10}$

Pregovori so postali tudi priljubljena vsebina osnovno- in srednješolskega učbeniškega gradiva, zlasti beril (Ulčnik 2014). Avtorji so jih navajali zaradi njihovega vzgojno-poučnega značaja, priročni pa so bili tudi zaradi izrazite retorične učinkovitosti, ki je pripomogla $\mathrm{k}$ hitremu pomnjenju. V učbeniškem gradivu so se pojavljale samostojne zbirke domačih in tujih pregovorov, PE pa so bile izpostavljene tudi v okviru vzgojno-poučnih zgodb (basni, prilike) in drugih poljudnostrokovnih prispevkov.

\footnotetext{
${ }^{8}$ Zanimivi so načini povezovanja pregovorov z znanstvenimi ugotovitvami na področju psihologije, npr. »Obleka naredi človeka, pravi star slovenski pregovor. In tudi psihologi ugotavljajo, da s tem, kako se oblačimo, kažemo svoj odnos do sveta in svoje osebnostne lastnosti« (vir: Gigafida).

${ }^{9}$ Podobno tudi Erika Kržišnik (2013) opozarja na različne vidike raziskovanja slovenske frazeologije, npr. kognitivnojezikoslovnega, etnoligvističnega, lingvokulturološkega.

${ }^{10}$ Fran Kocbek je kasneje v soavtorstvu z Ivanom Šašljem izdal obsežnejšo zbirko z naslovom Slovenski pregovori, reki in prilike (1934).
} 
Pregovori so bili pomembno in vedno izrazitejše leksikografsko gradivo. Prva večja zbirka slovenskih pregovorov je navedena že v Gutsmanovem nemško-slovenskem slovarju Deutsch-Windisches Wörterbuch (1789), ${ }^{11}$ številne PE najdemo tudi v Cigaletovem (1860) in Pleteršnikovem slovarju (1894/95). Uredniki slovarjev so $\mathrm{v}$ vedno večji meri zaznavali posebnosti PE, zaradi česar so nanje skušali opozarjati s posebnimi označevalniki, dokler jih niso v SSKJ (sicer še nedosledno) vključili v posebnem razdelku (prim. Ulčnik 2014a; Jesenšek, Ulčnik 2014: 278-280).

\section{Terminološka poimenovanja osnovne PE in njihovo razumevanje}

Slovarji razkrivajo različna poimenovanja osnovnih PE. V Pleteršnikovem slovarju (1894/95) za nemški izraz Sprichwort najdemo naslednje slovenske sopomenske ustreznice: (1) pregovor, (2) prigovor, (3) prislovica, (4) pripovest, (5) pravoč in (6) pravca. Ob njih so se v slovenskem prostoru uporabljali še izrazi prigliha, pravlica in poslovica. ${ }^{12}$

$\mathrm{V}$ sodobnem slovenskem jezikoslovju je uveljavljeno in splošno razširjeno poimenovanje pregovor, ki se je utrdilo in ustalilo že v 19. stoletju, v novejšem času pa se začenja pojavljati tudi izraz paremija. Ta ima nekoliko širši pomen, saj ob pregovorih zajema tudi reke in podobne enote (prim. Meterc 2014: 113); prevzet je iz drugih (slovanskih) jezikov in pri nas še ni leksikografsko evidentiran. ${ }^{13}$ Kot sopomenki paremiji se navajata tudi zvezi paremiološka enota oz. pregovorna enota. Posebni PE sta velerizem (wellerizem) in antipregovor, ki se analogno po tujih paremioloških raziskavah ${ }^{14}$ pojavljata tudi kot gradivo slovenskih znanstvenih prispevkov. Velerizem je opredeljen kot prenovitev PE, za katero je značilna tridelna zgradba - izhodiščno PE dopolnjuje podatek o govorcu in govorni situaciji, s čimer je dosežen humoren oz. ironičen učinek, npr. Naglica ni nikoli dobra, je rekel polž, ki je sedem let plezal na plot, potem pa padel z njega (Meterc 2013: 364). Za antipregovore je značilen satiričen ali parodičen poseg v zgradbo PE (Meterc 2014: 113), ki vpliva tudi na njegovo pomensko spremembo, oz. negacija PE, npr. Kar lahko storiš danes, odloži na jutri (Meterc 2014: 214), ${ }^{15}$ Roka roko umaže, Volk volku človek. Tovrstne enote $\mathrm{v}$ slovenščini sicer pogosto nastajajo, a večinoma niso ustaljene.

${ }^{11}$ Pregovore najdemo tudi v njegovi slovnici Windische Sprachlehre (1777).

${ }^{12}$ Izraz poslovica se še danes uporablja npr. v ruščini, hrvaščini in srbščini. Različna poimenovanja pregovorov prim. tudi v Stanonik 2014: 31-32.

${ }^{13}$ Paremija se že leta 1969 navaja v Enciklopedijskem riječniku lingvističkih naziva (P-Ž).

${ }^{14} \mathrm{Z}$ antipregovori sta se veliko ukvarjala Mieder in Litovkina. Prim. 15. poglavje v monografiji Introduction to Paremiology, 2015.

${ }^{15}$ Ta antipregovor se pojavlja tudi v drugih jezikih, npr. angleščini, madžarščini, ruščini, nemščini, francoščini (Introduction to Paremiology, 2015: 331). 
V 19. stoletju so pregovore razumeli zelo široko, saj so k njim prištevali tudi frazeme, gesla in podobno. Gradivo razkriva, da je bila tedaj paremiologija razumljena $\mathrm{v}$ širšem smislu, saj je zajemala tudi frazeme v današnjem ožjem pomenu besede. ${ }^{16}$ Poimenovanje pregovor (prislovica, poslovica ...) je bilo torej $\mathrm{v}$ preteklosti nadpomensko in je vključevalo tudi frazeme oz. frazeologijo v ožjem pomenu besede. Današnje stanje v slovenskem strokovnem prostoru pa je obratno: frazeologija je razvita jezikoslovna disciplina, ki v širšem pojmovanju zajema tudi pregovore in ima vidnejše rezultate v slovaropisju; paremiologija je v slovenistiki manj razvita, paremiološkim enotam pa je namenjena skromnejša strokovno-znanstvena pozornost. ${ }^{17}$ Četudi se je termin paremiologija v slovenskem jezikovnem prostoru pojavil že zelo zgodaj, do danes ob paremiologiji kot vedi in paremiografiji kot njeni sestavni veji, vezani na »zbiranje, zapisovanje in predstavitev pregovorov« (Babič 2011), ter pridevniku paremiološki v znanstvenih razpravah ne zasledimo poimenovanja za strokovnjaka (paremiolog), pa tudi mednarodni izraz paremija še ni ustaljen. ${ }^{18}$

19. stoletje

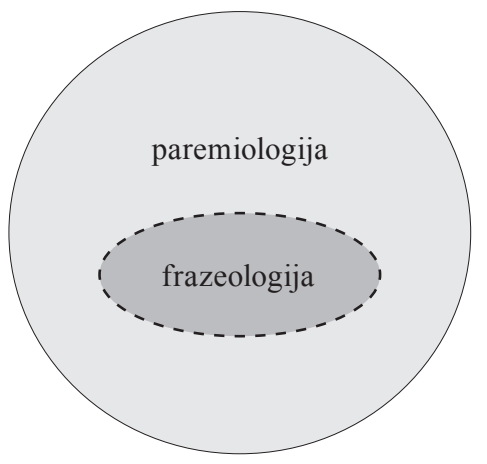

20. stoletje

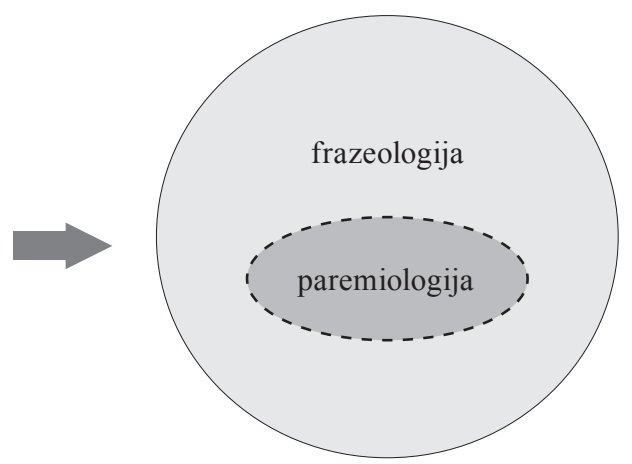

Shema 1: Razmerje med paremiologijo in frazeologijo

16 Tako je npr. frazem pretakati krokodilje solze (Keber 2011) v 19. stoletju opredeljen kot pregovor: »Star pregovor 'krokodilove solze toči' zaznamva človeka, ki na vides žaluje, $v$ resnici pa, to je, v sercu veselje obhaja o nesreči svojiga bližnjiga« (citat po Ulčnik 2014a).

${ }^{17}$ Pregovori so načeloma obravnavani v okviru širših frazeoloških tem, redkeje vzporedno ob frazemih (prim. Stramljič Breznik 2007) oz. povsem samostojno. Pregleden teoretičen prispevek o pregovorih v slovenščini najdemo pri Grzybek 2008; razvojni vidik je npr. obravnavan pri Jesenšek 2007 in Ulčnik 2011, nekaj je tudi kontrastivnih paremioloških raziskav (npr. Meterc 2013, 2014, Bernjak 2013). Opazno je, da je več raziskav, vezanih na slovenske pregovore, nastalo po letu 2010, in sicer v okviru projektov Frazeologija nemškega jezika, Slovensko-nemški medkulturni in kontrastivni vidiki ter Slovenski pregovori kot kulturna dediščina. Prispevki s skupne dvodnevne mednarodne konference so objavljeni v zborniku Več glav več ve, Frazeologija in paremiologija v slovarju in vsakdanji rabi (2014).

${ }^{18}$ Prim. Prilogo. 


\subsection{Nestrokovna poimenovanja PE}

Ob strokovnih poimenovanjih PE pa je zlasti v neumetnostnih besedilih pogosto tudi njihovo laično poimenovanje. V korpusu Gigafida najdemo ob izrazu pregovor in zvezah, kot so npr. star pregovor, slovenski pregovor, ljudski pregovor, star slovenski pregovor, ${ }^{19}$ tudi naslednja poimenovanja, ki so lahko tudi učinkovita uvajalna sredstva in pomoč pri prepoznavanju oz. iskanju pregovorov: citat, enačba, filozofija, formula, fraza, geslo, gesta, izrek, logika, maksima, misel, miselnost, (ljudska, stara) modrost, moto, načelo, obrazec, paradigma, parola, (življenjsko) pravilo, princip, (slovenski, nemški, latinski ...) rek, reklo, (stara) resnica, sistem, slogan, teorija, trditev, vizija, vodilo, zakon, zapoved ... Navedeno je ponazorjeno z zgledom Manj je več (podčrtala N. U.):

Še posebej graciozne in glamurozne boste videti v črnih, belih ali kožnih odtenkih čipke, zato nikar ne pretiravajte $\mathrm{z}$ ostalimi barvnimi odtenki. Tukaj velja načelo - manj je več.

Mrhasto se ji priklanjam, ker je še meni pospešila srčni utrip, ko je na svojem četrtkovem koncertu vstopila v dvorano. Tole je dober prikaz mota 'manj je več'. A kaj bi izgubljali besede, naj obleka govori zase!

Nič ne bo narobe, če boste svoje prste okrasili z več nakita, pazite le, da tedaj ne pretiravate še z drugimi modnimi dodatki. Še vedno namreč velja zlato pravilo - manj je več!

Frazo »manj je več« poznamo vsi. Na spletu je ta trend dobil zalet z Googlom, ki pa se, kot kaže, zdaj obrača v drugo smer. Vsaj če sklepamo po iskalniku, ki je najprej dobil fensi svetleče gumbe, zdaj pa še slike v ozadju.

Njihov logotip je sicer nekonvencionalen in preprost (logika »manj je več«) ter od ostalih strank v mnogo izrazitejši barvni kombinaciji (rumeni-oranžni-rdeči).

Slovenci, kot meni /.../, udejanjamo princip »manj je več«, saj smo kot majhen narod izjemno senzibilni do svojih korenin, hkrati pa premoremo tudi ogromno odprtosti do drugih kultur in jezikov.

Hrvatica se je držala priznanega reka »manj je več« in prišla v kopalkah ter držala v rokah dve verigi.

Tam ste modernizirali to postavko štipendije in ste znižali zadevo, postavko za skoraj

7 milijonov evrov. Očitno velja paradigma, manj je več.

Ta poimenovanja nas pogosto privedejo tudi do novejšega, še neevidentiranega paremiološkega gradiva ali do prenovitev znanih PE, npr. "po sistemu red mora biti, pa čeprav slab« (vir: Gigafida).

${ }^{19}$ Izraz paremija se pojavi le enkrat: $» V$ srednjem veku, ko je bila večina nepismena, bi človek predpostavljal odsotnost pravnega reda. Napak, paremije, pravni reki so vztrajno prehajali iz roda v rod: Če ugasne v hiši ogenj, ugasne pravica na gmajni ...« (vir: Gigafida). 


\section{Definiranje osnovne paremiološke enote}

Kljub današnjemu ločevanju med frazemi in PE še vedno obstajajo številne terminološke zagate, ki jih povzroča definicijska neenoznačnost. Pregovori v slovenskem jezikoslovju namreč še niso natančno definirani in razmejeni od podobnih jezikovnih enot. ${ }^{20} \mathrm{~V}$ Enciklopediji slovenskega jezika so PREGOVORI opredeljeni kot »staln/e/ zelo kratk/e/ oblik/e/ sporočila nekako svetovnonazorskega značaja, v katerem se (navadno v eni povedi) razodeva kakšno spoznanje, opažanje, tudi modrost« (Toporišič 1992: 210); pogosto gre za vzgojne enote z zgradbo povedi (imenovane tudi REČENICE). ${ }^{21}$ Od pregovorov so načeloma - vendar nenatančno - ločeni: (1) REKI, za katere velja, da jedrnato izrekajo »druge vrste misli, filozofske ali nravne narave« in imajo znanega tvorca (Toporišič 1992: 253), (2) AFORIZMI, zgoščeno izražene duhovite, globoke misli $\left(\mathrm{SSKJ}^{2}\right)$, prav tako z znanim avtorjem, (3) IZREKI, zgoščeno izražene duhovite, globoke misli $\left(\mathrm{SSKJ}^{2}\right)$ in (4) SENTENCE, zgoščeno izražene globoke misli, ki temeljijo na življenjski izkušnji (SSKJ $\left.{ }^{2}\right)$. Pregovorom sorodne so tudi MAKSIME (po SSKJ 2 življenjska vodila, gesla), SLOGANI oz. GESLA (kratko izražene programske misli) ipd.

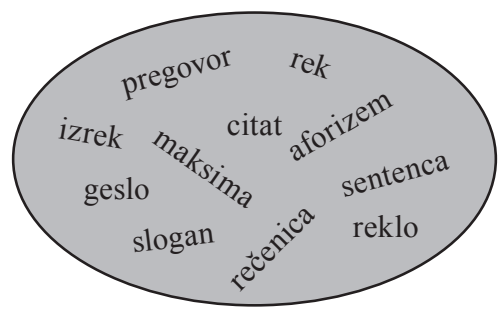

Shema 2: Razumevanje PE

V Enciklopediji Slovenije so pregovori opredeljeni kot »najkrajša oblika slovstvene folklorne ustvarjalnosti«, ki se lahko z različnimi nameni uporablja tudi v vsakdanjem govoru (Stanonik 1995: 275). Opozorjeno je na njihovo raznolikost glede na izvor, strukturo in sporočilo ter posledično težavnost razvrščanja (Stanonik 1995: 276).

Univerzalna definicija pregovora ne obstaja in je zaradi interdisciplinarne obravnave tudi ni možno pričakovati (prim. Grzybek 2008: 30-34). Vsaka veda namreč oblikuje svojo opredelitev enote in pri tem skladno z metodološkimi pristopi izpostavlja zanjo pomembne sestavine. V teološkem smislu imajo pregovori kot enote modrostne literature drugačno vrednost kot npr. v jezikoslovju in slovstveni folkloristiki (prim. Dolenc 2014). V vedah, ki se raziskovalno posvečajo pregovorom, pa se pojavljajo nekatere osnovne, vendar ne absolutne

${ }^{20}$ Kržišnik (2013: 15) podobno opozarja tudi za frazeme kot osnovne frazeološke enote (FE), pri tem pa izpostavlja odvisnost določanja FE od uporabljenih teoretičnih pristopov.

${ }^{21}$ rečeníca -e ž (í) neobč.: razlaga rečenic v slovarju rekel, fraz; pregovor; poud. prazne $\sim$ |fraze|; jezikosl. |stalna besedna zveza, ki je poved| (SP 2001) 
značilnosti pregovorov: (1) izražanje LJUDSKE MODROSTI, SPLOŠNIH RESNIC, temelječih na življenjskih izkušnjah; (2) MEDGENERACIJSKO IZROČILO (kulturna dediščina, prenašanje iz roda $v$ rod); (3) SPLOŠNO POZNAVANJE (ob tem se odpira vprašanje t. i. paremiološkega minimuma oz. paremiološkega optimuma, tj. nabora »enot, ki so znane in razumljive večini govorcev« (Meterc); v neposredni povezavi s poznavanjem pregovorov je njihova vsesplošna prisotnost (vsakdanja komunikacija, govorjeni, pisni, elektronski mediji, sodobna umetnost, ${ }^{22}$ oglaševanje ${ }^{23}$...); (4) NEZNANO AVTORSTVO (četudi so jih ustvarili posamezniki; po tem kriteriju je pregovore mogoče ločevati od rekov, aforizmov, sloganov, vendar tudi te enote pogosto prehajajo $\mathrm{v}$ pregovorno rabo, avtorstvo pa stopa v ozadje); ${ }^{24}$ (5) MIKROBESEDILNA ZGRADBA (zaokroženost, zgoščenost, zgradba povedi, citatna raba ali integracija $\mathrm{v}$ besedilo in $\mathrm{z}$ njo povezana relativna strukturna stabilnost - možnost modifikacij); (6) IDIOMATIČNOST/ METAFORIČNOST (prenesen pomen; obenem tudi možnost t. i. dvojnega branja pregovorov, torej njihovo preneseno in dobesedno razumevanje, npr. Majhni otroci, majhne skrbi, veliki otroci, velike skrbi); (7) FIGURATIVNOST (rima, aliteracija, asonanca, personifikacija, hiperbola, paralelizem, elipsa ipd. - v funkciji retorične učinkovitosti in lažje zapomnljivosti); (8) EKSPRESIVNOST (slikovitost, konotativnost); (9) VEČFUNKCIONALNOST (poučnost/didaktičnost; podkrepitev izrečenega, nestrinjanje z izrečenim, ironizacija; opozorilo, svarilo, grožnja, nasvet, smernica, opravičilo, spodbuda, tolažba, sklep, argument ...); (10) hranjenje enot V MENTALNEM SPOMInU (prim. Stanonik 1995, Mieder 2004, Jesenšek 2007, Grzybek 2008, Babič 2010, Norrick 2015).

Problematično ločevanje pregovorov od njim sorodnih enot, npr. frazemov, ${ }^{25}$ sloganov in gesel, ki pogosto prehajajo $\mathrm{k}$ pregovorom, lahko ponazorimo $\mathrm{z}$ naslednjimi zgledi: (1) PE Vsi smo v istem čolnu ali frazem (kdo) biti v istem čolnu; (2) PE Ti je muca jezik snedla/popapala/popapcala/papala/pojedla? ali frazem ti je muca jezik snedla/muca je snedla jezik komu; ${ }^{26}$ (3) slogan ali pregovor Vsi drugačni, vsi enakopravni. ${ }^{27}$

Kaže, da lahko tudi o paremiologiji/pregovoroslovju govorimo v: (1) ožjem in (2) širšem smislu. Pri (1) zajamemo zgolj pregovore, pri (2) pa vse PE (torej pregovore in njim sorodne enote).

${ }^{22}$ Izviren pristop k pregovorom je izbral Jaka Železnikar, ki je v povezavi jezika z umetnostjo ustvaril kontaminirane pregovore, npr. Brez sreče se še čevelj ne obuje. Prim. Železnikar.

${ }^{23}$ Prim. Babič 2010.

${ }^{24} \mathrm{~V}$ korpusih so izpričane kolokacije, ki pregovore definicijsko opredeljujejo v smislu ljudskosti in starosti, npr. ljudski pregovor, star pregovor.

${ }^{25}$ Mnogi frazemi so paremiološkega izvora, npr. Kdor visoko leta, nizko pade > visoko letati, nizko pasti (Kržišnik 2013: 15); Nova metla dobro pometa > nova metla.

${ }^{26} \mathrm{~V}$ Slovarju slovenskih frazemov najdemo pod iztočnico máčka različici mačka je snedla jezik komu in muca je snedla jezik komu (Keber 2011: 496), pod iztočnico múca pa vprašalno obliko ti je muca jezik snedla (Keber 2011: 556).

${ }^{27}$ Enota namreč po svojih značilnostih zadostuje kriterijem pregovorov (Babič 2011: 155). 


\section{Raziskovanje PE in njihovo paremiografsko prikazovanje}

V slovenistiki je bila znanstvena pozornost usmerjena zlasti na formalni in jezikovnozgodovinski oz. etimološki vidik pregovorov, drugi pristopi (prim. pogl. 1.1) pa so se pojavili šele v zadnjih letih. Tudi Erika Kržišnik v zaključku prispevka Moderna frazeološka veda v slovenistiki paremiološko področje izpostavi kot jezikoslovno premalo raziskano:

Kaj res pogrešamo? Kratek pregled med drugim tudi razkrije, da se v slovenistični frazeologiji od prvega Toporišičevega frazeološkega članka dalje ne razpravlja več o teoretičnih problemih relativno samostojnega dela frazeologije, ki zajema t. i. rečenice, zlasti pregovore in reke, vsaj ne z jezikoslovnega vidika. (Kržišnik 2013: 25)

$\mathrm{V}$ prihodnje bi morali $\mathrm{v}$ znanstvenih raziskavah $\mathrm{v}$ večji meri opozoriti na novejše PE, ki so del našega vsakdana (oglaševanje, elektronski mediji ipd.) in so zajete tudi v korpusnem gradivu, saj še niso bile deležne zadostne jezikoslovne analize oz. zadostne paremiografske pozornosti. Raziskati bi bilo treba skladenjsko modelnost in konektorsko vpetost pregovorov v sobesedilno okolje ter problematiko razumevanja pregovorov (idiomatičnost, vpliv jezikovne in kulturne kompetence; pojasnjevanje pomena pregovora v sobesedilu, navezovalne prvine, sobesedilna opozorila na napačno razumevanje povedanega/zapisanega pregovora, neafirmativnost pregovorov). ${ }^{28}$ Zanimivo bi bilo raziskovati tudi slovensko paremiološko gradivo v govorjenih besedilih, ${ }^{29}$ upoštevajoč različne sociolingvistične parametre. ${ }^{30}$ Razmerje rabe pri otrocih in odraslih je določeno zgolj površinsko (otroci naj bi primerjalno z odraslimi pregovore uporabljali v manjši meri, natančnejših raziskav za slovenščino pa ni). Že površen pregled forumskih besedil, ki se pogosto približujejo govorjenemu jeziku, pa pokaže, da otroci uporabljajo nekatere specifične PE, katerih raba lahko v odrasli dobi zamre, npr. jaja zdaj je že prepozno...prva beseda velja, druga pa se v koš da (Forum Š́GT).

Slovensko-nemška paremiološka problematika je z različnih vidikov, npr. formalno-skladenjskega, semantično-pragmatičnega, kulturološkega, sociolingvističnega, leksikološko-leksikografskega in didaktičnega, že predstavljena v monografskih publikacijah (npr. Jesenšek 2008, Fabčič, Bernjak 2014, Lipavic Oštir 2014). Pomembna je tudi kontrastivna raziskava, ki jo je v okviru doktorske disertacije pod mentorstvom Jozefa Pallaya in Petra Durča opravil Matej Meterc. V reviji Slavia Centralis je bil objavljen tudi slovenski paremiološki minimum - seznam petdesetih najbolj poznanih slovenskih pregovorov (prim. Ďurčo, Meterc 2013), ki je lahko dobra osnova za nadaljnje paremiološke (kontrastivne) raziskave $\mathrm{v}$ slovenskem prostoru.

\footnotetext{
${ }^{28} \mathrm{Na}$ zanimiv vidik raziskovanja »pregovorov, ki ne držijo«, je v diskusiji na simpoziju Slovaropisna dejavnost na Slovenskem opozoril Marko Snoj.

${ }^{29}$ Korpus GOS prinaša malo tovrstnega gradiva.

${ }^{30}$ Obsežnejša sociolingvistična raziskava slovenskih pregovorov je nastala v okviru projekta Frazeologija nemškega jezika (prim. Lipavic Oštir 2014).
} 


\section{Sklep}

Pregovornim enotam je v okviru slovenskega jezikoslovja posvečenih vse več znanstvenih prispevkov in $\mathrm{v}$ njih se zlasti pod vplivom tujih paremioloških raziskav razvija tudi posebna terminologija, npr. paremija, antipregovor, velerizem, paremiografija. Opazno je, da je paremiologija v slovenskem prostoru sicer še zmeraj praviloma obravnavana v okviru frazeologije, a se v posameznih primerih skuša tudi osamosvojiti. To je bilo očitno tudi na dvodnevni mednarodni znanstveni konferenci, organizirani aprila 2013 v Mariboru in Ljubljani: Več glav več ve, Frazeologija in paremiologija v slovarju in vsakdanji rabi. Navedeno lahko razumemo kot smernico nadaljnjim samostojnim jezikoslovnim paremiološkim raziskavam, ki bodo gotovo pripomogle tudi $\mathrm{k}$ razreševanju terminološke problematike.

\section{VIRI IN LITERATURA}

Saša BABIČ, 2010: Sodobne modifikacije pregovorov, frazemov in drugih folklornih obrazcev. Slavica Slovaca 45/2, 154-161.

- -, 2011: Paremiologija - na križišču jezikoslovja in slovstvene folkloristike. Meddisciplinarnost v slovenistiki. Ur. Simona Kranjc. (Obdobja 30). 27-31.

Elizabeta BERNJAK, 2013: Slovenski in madžarski pregovori o zdravju. Slovenski jezik v stiku evropskega podonavskega in alpskega prostora. Ur. Marko Jesenšek. Maribor: Mednarodna založba Oddelka za slovanske jezike in književnosti. (Zora 93). 337-343.

Bogdan DOLENC, 2014: Pregovori v Svetem pismu. Več glav več ve: Frazeologija in paremiologija v slovarju in vsakdanji rabi. Ur. Vida Jesenšek, Saša Babič. Maribor: Filozofska fakulteta, Oddelek za germanistiko; Ljubljana: ZRC SAZU, Inštitut za slovensko narodopisje. $42-60$.

Peter ĎURČO, Matej METERC 2013: Empirične paremiološke raziskave tipov ekvivalentnosti in suprasemantičnih razlik v slovenščini in slovaščini. Slavia Centralis VI/2, $20-36$.

- -, 2014: Ekvivalentnost slovaških in slovenskih pregovorov. Pristop k tipologiji ekvivalentnosti. Več glav več ve: Frazeologija in paremiologija v slovarju in vsakdanji rabi. Ur. Vida Jesenšek, Saša Babič. Maribor: Filozofska fakulteta, Oddelek za germanistiko; Ljubljana: ZRC SAZU, Inštitut za slovensko narodopisje. 80-96.

Enciklopedijski riječnik lingvističkih naziva (P-Ž). Zagreb: Matica Hrvatska, 1969.

Melanija Larisa FABČIČ, Elizabeta BERNJAK, 2014: Frazemi in pregovori v stiku. Kulturološki in semantično-pragmatični vidiki. Maribor: Filozofska fakulteta, Oddelek za germanistiko.

Forum SŠGT. Dostopno 9. 4. 2015 na: http://ssgt1991maribor.superforum.fr/t21-nasi-solski-problemi.

Gigafida - korpus slovenskega jezika. Dostopno 9. 4. 2015 na: http://www.gigafida.net/. GOS - korpus govorjene slovenščine. Dostopno 9. 4. 2015 na: http://www.korpus-gos.net/. 
Peter GRZYBEK, 2008: Fundamentals of Slovenian Paremiology. Traditiones 37/1, $23-46$.

- -, 2013: Macrostructural problems of paremiography/proverb lexicography. Več glav več ve: Frazeologija in paremiologija v slovarju in vsakdanji rabi. Povzetki. Ljubljana, Maribor. 26-28.

Introduction to Paremiology. Ur. H. Hrisztova-Gotthardt, M. Aleksa Varga. Dostop 5. 5. 2015 na: http://www.degruyter.com/viewbooktoc/product/449649.

Vida JESENŠEK, 2007: Pregovori med preteklostjo in prihodnostjo. Besedje slovenskega jezika. Ur. Marko Jesenšek. Maribor: Slavistično društvo. (Zora 50). 276-290.

- -, 2008: Begegnungen zwischen Sprachen und Kulturen, Beiträge zur Phraseologie. Bielsko-Biała: Akademia Techniczno-Humanistyczna.

Vida JESENŠEK, Natalija ULČNIK, 2014: Spletni frazeološko-paremiološki portal: redakcijska vprašanja ob slovenskem jezikovnem gradivu. Več glav več ve: Frazeologija in paremiologija v slovarju in vsakdanji rabi. Ur. Vida Jesenšek, Saša Babič. Maribor: Filozofska fakulteta, Oddelek za germanistiko; Ljubljana: ZRC SAZU, Inštitut za slovensko narodopisje. 276-292.

Janez KEBER, 2011: Slovar slovenskih frazemov. Ljubljana: Založba ZRC, ZRC SAZU.

Erika KRŽIŠNIK, 2004: Pojmovanje metafore v kognitivnem jezikoslovju: čas je denar - tako rečemo $=$ tako mislimo. Slovenski jezik in literatura $v$ evropskih globalizacijskih procesih. Ur. Marko Jesenšek. (Zbornik Slavističnega društva Slovenije, 15). Ljubljana: Slavistično društvo Slovenije. 56-74.

- -, 2008: Viri za kulturološko interpretacijo frazeoloških enot. Jezik in slovstvo 53/1, $33-47$.

- -, 2013: Moderna frazeološka veda v slovenistiki. Frazeološka simfonija: Sodobni pogledi na frazeologijo. Ur. Nataša Jakop, Mateja Jemec Tomazin. Ljubljana: Založba ZRC. 15-26.

Alja LIPAVIC OŠTIR, 2014: Nemški in slovenski pregovori: Sociolingvistični vidiki. Maribor: Filozofska fakulteta, Oddelek za germanistiko.

Matej METERC, 2013: Antonimija enako motiviranih paremioloških enot (primeri iz slovenščine in slovaščine). Slavistična revija 61/2, 361-376.

- -, Vprašalnik o poznavanju in razumevanju pregovornih enot (paremij) za slovenski paremiološki optimum. Dostopno 9. 4. 2015 na http://vprasalnik.tisina.net/.

Matej METERC, 2014: Je prihodnost slovenskih antipregovorov (le) pregovorna? Prihodnost $v$ slovenskem jeziku, literaturi in kulturi. Ur. Hotimir Tivadar. Ljubljana. 113-116.

Wolfgang MIEDER, 1994: Paremiological Minimum and Cultural Literacy. Wise Words, Essays on the Proverb. Ur. W. Mieder. New York, London: Garland Publishing. 297-316.

- -, 2004: Proverbs: A handbook. Westport, Connecticut: Greenwood Press.

Neal R. NORRICK, 2015: Subject Area, Terminology, Proverb Definitions, Proverb Features. Introduction to Paremiology. Ur. H. Hrisztova-Gotthardt, M. Aleksa Varga. Dostop 5. 5. 2015 na: http://www.degruyter.com/viewbooktoc/product/449649.

Martina OŽBOT, 2011: Interdicsiplinarnost - je sploh (še) mogoče drugače? Meddisciplinarnost v slovenistiki. Ur. Simona Kranjc. Ljubljana. (Obdobja 30). 351-356. 
Pleteršnikov Slovensko-nemški slovar. Spletna izdaja. Ljubljana: ZRC SAZU, Inštitut za slovenski jezik Frana Ramovša ZRC SAZU, 2010. Dostopno 9. 4. 2015 na: http://bos. zrc-sazu.si/pletersnik.html.

SSKJ²: Slovar slovenskega knjižnega jezika. Ljubljana: Založba ZRC SAZU, 2014.

SP 2001: Slovenski pravopis 2001. Spletna izdaja. Ljubljana: Založba ZRC SAZU, 2010. Dostopno 9. 4. 2015 na: http://bos.zrc-sazu.si/sp2001.html.

Marija STANONIK, 1995: Pregovor. Enciklopedija Slovenije 9. Plo-Ps. Ljubljana: Mladinska knjiga. 275-276.

- -, 2014: Slovenski pregovori kot kulturna dediščina: klasifikacija in redakcija korpusa. Predstavitev projekta. Več glav več ve: Frazeologija in paremiologija v slovarju in vsakdanji rabi. Ur. Vida Jesenšek, Saša Babič. Maribor: Filozofska fakulteta, Oddelek za germanistiko; Ljubljana: ZRC SAZU, Inštitut za slovensko narodopisje. 26-38.

Irena STRAMLJIČ BREZNIK, 2007: Družina v slovenskih pregovorih in frazemih. Frazeologija v jezikoslovju in drugih vedah. Ur. Erika Kržišnik, Wolfgang Eismann. Ljubljana: Filozofska fakulteta, Oddelek za slovenistiko. 251-266.

Jože TOPORIŠIČ, 1992: Enciklopedija slovenskega jezika. Ljubljana: Cankarjeva založba.

Natalija ULČNIK, 2011: Pregovori v procesu spreminjanja. Slavistika v regijah - Maribor. Ur. Boža Krakar Vogel. Ljubljana: Zveza društev Slavistično društvo Slovenije. (Zbornik Slavističnega društva Slovenije, 22). 63-68.

- -, 2014: Pregovor je najboljši učitelj. Vloga in pomen pregovorov pri pouku slovenščine v 19. stoletju in danes. Frazeologija nemškega jezika z vidikov kontrastivnega in uporabnega jezikoslovja. Ur. Vida Jesenšek. Maribor: Filozofska fakulteta, Oddelek za germanistiko. 36-58.

- -, 2014a: Slovensko paremiološko in frazeološko gradivo v temeljnih dvojezičnih slovarjih 19. stoletja - v Cigaletovem nemško-slovenskem (1860) in Pleteršnikovem slovensko-nemškem slovarju (1894/95). Frazeologija nemškega jezika z vidikov kontrastivnega in uporabnega jezikoslovja. Ur. Vida Jesenšek. Maribor: Filozofska fakulteta, Oddelek za germanistiko. 282-319.

Mojca ŽAGAR KARER, 2011: Definicije v slovenskih terminoloških slovarjih. Izzivi sodobnega slovenskega slovaropisja. Ur. Marko Jesenšek. Maribor: Filozofska fakulteta, Mednarodna založba Oddelka za slovanske jezike in književnosti. (Mednarodna knjižna zbirka Zora, 75). 124-138.

Jaka ŽELEZNIKAR. Dostopno 9. 4. 2015 na: http://www.jaka.org/.

\section{PRILOGA: SEZNAM NEKATERIH STROKOVNIH IZRAZOV S PODROČJA PAREMIOLOGIJE}

antipregovor antipregovor $\mathrm{z}$ repom

slovenski antipregovor neustaljen antipregovor ustaljen antipregovor tvorba antipregovora 


\begin{tabular}{|c|c|}
\hline paremija & $\begin{array}{l}\text { slovenska paremija } \\
\text { sopomenska paremija } \\
\text { protipomenska paremija }\end{array}$ \\
\hline paremiografija & slovenska paremiografija \\
\hline paremiolog & $\begin{array}{l}\text { ameriški paremiolog } \\
\text { madžarski paremiolog } \\
\text { slovaški paremiolog }\end{array}$ \\
\hline paremiologija & $\begin{array}{l}\text { empirična paremiologija } \\
\text { kontrastivna paremiologija } \\
\text { narečna paremiologija } \\
\text { slovenska paremiologija }\end{array}$ \\
\hline paremiološki & $\begin{array}{l}\text { paremiološka analiza } \\
\text { paremiološka enota } \\
\text { paremiološka kompetenca } \\
\text { paremiološka raziskava } \\
\text { paremiološka terminologija } \\
\text { paremiološka tvorba } \\
\text { paremiološka varianta } \\
\text { paremiološka zbirka } \\
\text { paremiološka zgradba } \\
\text { paremiološki minimum } \\
\text { paremiološki optimum } \\
\text { paremiološki žanr } \\
\text { paremiološko gradivo }\end{array}$ \\
\hline pregovor & $\begin{array}{l}\text { knjižni pregovor } \\
\text { narečni pregovor } \\
\text { narodni pregovor } \\
\text { ljudski pregovor } \\
\text { protipomenski pregovor } \\
\text { sopomenski pregovor } \\
\text { slovenski pregovor } \\
\text { star pregovor } \\
\text { svetopisemski pregovor } \\
\text { vremenski pregovor }\end{array}$ \\
\hline pregovoren & $\begin{array}{l}\text { pregovorna enota } \\
\text { pregovorni ustreznik } \\
\text { pregovorno gradivo }\end{array}$ \\
\hline pregovoroslovje & slovensko pregovoroslovje \\
\hline rečenica & $\begin{array}{l}\text { slovenske rečenice } \\
\text { reklo in rečenica }\end{array}$ \\
\hline rek & $\begin{array}{l}\text { ljudski rek } \\
\text { slovenski rek } \\
\text { pregovori in reki }\end{array}$ \\
\hline velerizem oz. wellerizem & $\begin{array}{l}\text { neustaljen velerizem } \\
\text { ustaljen velerizem }\end{array}$ \\
\hline
\end{tabular}




\section{DEVELOPMENT OF THE SLOVENE PAREMIOLOGY AND PAREMIOLOGICAL TERMINOLOGY}

Recently the interest in paremiology has increased in Slovenia. Though in most cases in Slovene linguistics this interdisciplinary field is researched as a part of phraseology, certain attempts have been made to establish an independent status for paremiology. These trends have been particularly exposed at an international conference in Maribor and Ljubljana in 2013, in which both fields were distinguished in the name of the conference: Več glav več ve, Frazeologija in paremiologija v slovarju in vsakdanji rabi (Two heads are better than one, Phraseology and paremiology in dictionaries and in everyday use). Alongside the development of paremiology in Slovenia, terminology has also begun to expand, following the example of foreign terms such as anti-proverb (Antisprichwort, антипословица); wellerism; рагетіа (паремия) the expressions antipregovor, velerizem and paremija occured. As equivalent expressions to paremija paremiološka enota or pregovorna enota have also entered the language. Hence, proverbs as basic paremiological units have not been clearly defined and categorized according to related units (e. g. sayings, catchwords) yet. Thus, one of the primary goals of Slovene paramiological research is the establishment of a new terminology. 